\title{
Using Flipped Learming for Enhancing Faculty of Education English Majors' Reflective Teaching Skills and Learning Autonomy
}

\section{Dr. Marwa Gamal Muhammad Shehata}

TEFL Lecturer at the Dept. of Curriculum \& Instruction Faculty of Education- Minia University

\section{Abstract}

The present study aimed at investigating the use of
flipped learning for enhancing Faculty of Education
English Majors' Reflective Teaching Skills and Learning Autonomy. A quasi-experimental pretest- posttest control group design was employed. Seventy third year Faculty of Education English majors in the academic year 2017-2018 were randomly divided into two intact groups: a treatment group and a non-treatment one. A teacher's guide was designed by the researcher in the light of the flipped learning strategy and used with the treatment group, whereas, the conventional way of instruction was used with the non-treatment group. The data of the study were gathered by a pre-post reflective teaching skills test and a learning autonomy scale. Instruments of the study included a needs assessment questionnaire on the reflective teaching skills, a language proficiency test, a reflective teaching skills test and a learning autonomy scale. Analysis of data obtained showed that the treatment group achieved a higher degree of improvement in the post testing than the non- treatment group on both the reflective teaching skills test and the learning autonomy scale. Recommendations and suggestions for further research were presented.

Key words: Flipped learning - Reflective Teaching Skills- Learning Autonomy

\section{Introduction:}

In modern societies, information is becoming available and changing more rapidly prompting users to continuously rethink and switch their directions. Therefore, it is increasingly important to prompt reflective thinking as a lifelong learning skill during learning to help learners develop strategies to apply 
new knowledge to the complex situations they face in their day to day situations.

In Education, the conventional teacher-centered approach, which emphasizes content instruction, is not appropriate for today's learners who are ' digital natives', and have grown up with computers, videos, video games and the Internet. Therefore, technology should play a vital role in classroom setting.( (Kiran,2014; Yang 2017).

Bergmann and Sams (2014) highlight that meaningful learning occurs when students have the knowledge and cognitive processes needed for problem solving. Flipped learning involves students interacting with new knowledge in their individual learning space so that the group learning space can be an interactive and dynamic environment to practice and deepen knowledge.

James, Chin \& Williaams (2014) mention that flipped classroom teaching techniques are a pedagogical form of blended learning where the traditional classroom is flipped or inverted by delivering "instruction" outside the classroom and then bringing the "application" of learning outcomes into the teaching space.

EDUCAUSE (2012) assures that the flipped model puts more of the responsibility for learning on the shoulders of students while giving them motivation to experiment. Activities can be student-led, and communication among students can become the determining dynamic of a session devoted to learning through hands-on work.

The advantage of flipped learning is that students can interact with new content in their individual learning space so that more class time can be spent in practicing and deepening the knowledge. Effective flipped learning includes meaningful and authentic learning experiences to practice procedural knowledge and deepen declarative knowledge. The philosophy behind the flipped classroom teaching methodology is that it allows instructors to teach both content and process. (Kiran 2014 ; Hamad 2016). 
Moreover, using the flipped classroom pedagogy can encourage students' reflection and develop their reflective abilities because they need to reflect on the connection between the course materials they have prepared prior to the lessons and activities in classes. (Roehl et al., 2013; Vaughan, 2014)

Yang (2017) also states that in the flipped classroom, students have the ownership of their learning because of the availably of pre- recorded lesson videos. In other words, the flipped classroom can promote students' deeper understanding of knowledge and concepts, and make them successful in learning.

In the flipped classroom, the instructor's main challenge is to design leaning experiences that engage students in higher level thinking and problem solving during the class time such as analyzing, synthesizing and evaluating. Students through inverted classrooms can have the chance to think reflectively on the connection between the course material they have prepared prior to lessons and activities conducted in classes.(Honeycutt \& Warren 2014;Vangughan 2014; and Roehl et.al., 2013; Stayer 2012)

Moreover, Chee \& San (2012) assure that for promoting reflective practices among teachers, the following four skills need to be enhanced; assumption analysis, contextual awareness, imaginative speculation and reflective skepticism as they are indicative of reflection.

Reflective teaching occurs when instructors and educators gather information about instruction, inspect their settings, convictions, suppositions and performance practices and utilize the data collected a premise for basic reflection and instruction. Reflective teaching is the main force to improve for better learning arrangements with respect to instructors. Recent generations are well informed and behaviorally intelligent therefore, instructors must be upgraded and provide learning environment that really stimulate learners' reflection and 
interest. (Al-Ahdal\& Abdullah 2014; Matchett2005; Tochon 1999)

Based on what was mentioned above it is advisable that EFL Teachers should provide the appropriate environment and activities that can promote and support reflective thinking and teaching skills. Below are some characteristics of such an environment as listed by Moon (1999) \& Halpern (1996) were they see that instructors should:

1. provide enough wait-time for students to reflect when responding to inquiries.

2. provide emotionally supportive environments in the classroom encouraging reevaluation of conclusions.

3. prompt reviews of the learning situation, what is known, what is not yet known, and what has been learned.

4. provide authentic tasks involving less-structured data to encourage reflective thinking during learning activities.

5. prompt students' reflection by asking questions that seek reasons and evidence.

6. provide some explanations to guide students' thought processes during explorations.

7. provide a less-structured learning environment that prompts students to explore what they think is important.

8. provide social-learning environments such as those inherent in peer-group works and small group activities to allow students to see other points of view.

9. provide reflective journals to write down students' positions, give reasons to support what they think, show awareness of opposing positions and the weaknesses of their own positions.

For promoting reflective teaching TEFL instructors should logically promote learning autonomy. In this respect Woolfe (1992) suggested four components of experiential learning; "Student" is the first one of it. It suggested that the students know the process which are taking place, and which help in learning. The second suggests that the students are involved in a 
reflective practice. The third one is about experience and content that includes what is being learned and how it is being learned that play a crucial role for the person. The last one is that the student is engaged as a whole person. All the components suggest that a student is an active participant of classroom environment and learns to become responsible for his/ her learning, which composes the basic units of learner autonomy concept.

Therefore, a great deal of attention should be also paid by scholars to develop students' learning autonomy. Educators and teachers should take this responsibility over their own shoulders. They should always provide educational environments that can stimulate learners' to learn, to think and to search for information by their own selves.

Teachers are supposed to create a learning environment that enables students to make independent decisions and become productive. This is because - according to the constructivist approach - one of the significant goals of education is to promote learner autonomy. (Castle,2004; Ozturk, 2011)

Sinclair (2002) suggests thirteen aspects of learning autonomy which appeared to have been recognized and broadly accepted by the language teaching profession. One of them is that developing autonomy requires conscious awareness of the learning process such as conscious reflection and decision making. For this, Benson (2011) identifies six different approaches for fostering learners' autonomy: resource-based, technology-based, learner-based, classroom-based, curriculumbased and teacher-based approaches. The resource-based and technology-based approaches refer mainly to the out-of class strategies that aim at promoting learner autonomy, Whereas, the four latter approaches are within a classroom context.

Moreover, Borg \& Al-Busaidi (2012) provide some strategies for implementing learner autonomy such as reflective journals, project based learning, self -access center with appropriate materials and guidance /training, teacher- student 
conferences during office hours, learner generated materials and E-learning tools.

\section{Review of Literature:}

Below is an extensive review of literature on the application of flipped learning, reflective teaching and learning autonomy across the disciplines and their relationship to each other impacting the performance of teachers and student teachers.

\section{Studies Related to the Use of Flipped Learning :}

Considerable research has been conducted on the use of the flipped learning in Education- which was firstly proposed by Jonathan Bergman and Aarons Sams in 2006- such as the study conducted by Lee \& Lai (2017) which was conducted with the aim of facilitating higher-order thinking with flipped classrooms. The study adopted the "flipped classroom" approach in information and communication technology (ICT) class. The study examined student perceptions of the new teaching approach and investigated whether it could help promote higherorder thinking. This study involved 28 students attending an ICT class on 3D modeling. A mixed methods approach was adopted. The researchers concluded that it is possible to improve students' higher-order thinking capability using the flipped classroom approach in teaching.

More recently, Abdel-Fattah (2017) investigated the effectiveness of adopting flipped learning approach and the changes implemented to "Introduction to Applied Linguistics" course at English department, College of Administrative and human sciences in Qassim private colleges. Participants were thirty three fourth level students in the English department. Results revealed that adopting flipped learning approach yielded significant effects on students' linguistic level.

Moreover, Alsowat (2016) investigated the effect of a suggested EFL Flipped Classroom Teaching Model (EFL- FCTM) on graduate students' English higher order thinking skills (HOTS), engagement and satisfaction thinking skills, engagement 
and satisfaction on a sample comprised of (67) graduate female students; an experimental group ( $\mathrm{N}=33$ ) and a control group $(\mathrm{N}=34)$, studying an English course at Taif University, KSA. The study used mixed method design; a pre-post HOTS test was carried out and two 5 point-Likert scale questionnaires had been designed and distributed; an engagement scale and a satisfaction scale were also used. Findings revealed the effectiveness of the suggested program on developing students' higher order thinking skills, engagement and satisfaction.

In the same year, Fauzi \& Hussein conducted a study with the aim of producing an instructional design that could accommodate different learning styles and preferences in the flipped classroom. A design based research approach was employed in three phases (pre-liminary, prototyping phase and assessment phase in a flipped communication classroom of 24 students. Findings revealed the effectiveness of the suggested design in prompting learners' engagement and thinking skills.

In addition, Ahmed (2016) conducted a study to investigate the effect of the flipped classroom model on Egyptian EFL students' listening comprehension using a one-group preposttest. The sample included thirty four third year EFL students' at the Faculty of Education -Suez University. Ahmed concluded that flipped classroom has a significant effect on the listening comprehension of Egyptian EFL students.

One more important study that used flipped learning is the study of Al-Bassuony (2016) who investigated the effectiveness of flipped learning in improving English grammatical performance in speaking and writing of underachieving language learners. Participants consisted of forty nine first year secondary stage students at Port-Said military secondary school for boys. The study revealed that flipped learning significantly developed English grammatical performance in speaking and writing of both underachieving language learners and their normal peers

Matwejczyk \& Alexandar (2016) concluded in their study about applying flipped learning to placement preparation and 
employability skills that despite the importance of reflective practice, the literature and experts agreed that this skill is not taught well and by final year students have disengaged from it. Employers want graduates competent at reflective practice and other employability skills such as effective communication, interpersonal skills, teamwork and competency managing a demanding workload. Placement readiness and teaching employability skills can be effectively done through flipped learning.

Other researchers assured that flipped learning can afford students a more engagement environment that can lead a higher achievement and a better preparedness for $21^{\text {st }}$ century learning and work environments. They believed that the flipped concepts offered new directions that would help education institutions to meet the expectations of today's students by providing modern teaching and learning resources. Educators who use the flipped classroom could add additional supporting elements like assessment for learning, problem based inquiry, strategies for differentiation and could create an environment for instruction that is flexible than conventional classroom settings. (Lin, P \& Chen 2016; Jarod 2014; Kiran 2014; Graham 2013)

Other researchers asserted the impact of flipped classroom approach in Education that this approach is rooted in social constructivist theories that emphasize the active role of the learner in making meaning through social interaction. It provides the affordances of student engagement, differentiated instruction, and access to instructional media, inclusive practices, and a sense of community belonging. In their studies, they conclude that students displayed positive feelings towards flipped classrooms. ( Cara 2012; Terteault 2006).

\section{Studies Related to Reflective Teaching:}

Several disciples of instruction had been used by researchers to develop students' reflective teaching such as:

Action research was used as reflective technique in the study conducted by Emran (2016) and Blazquez (2007). Emran 
was investigating the effectiveness of a program on action research skills in developing $3^{\text {rd }}$ year English majors' reflective teaching in teaching practice and their professional attitude. Data analysis using t-test revealed that the post administration of students' performance significantly surpassed their performance in the three tools. Blazquez used action research for the purpose of enhancing teachers' ability to identify and solve problems by engaging them in a critical and reflective attitude.

Awad (2009) designed a reflective teaching model with the purpose of developing English majors' self-assessment, selfesteem and teaching skills. It was concluded from her study that English majors had developed flexibility and readiness for both creativity and change as they went beyond knowing theory to being able to use it appropriately as they understood the broader implications of their learning.

Besides exploring the impact of a reflective training model on instructional practice, Ellison (2008) further added another variable that is; students' classroom behavior. Specific focus was on training whereby teachers were guided through a reflective make-and-take development curriculum and instructional materials to use in classroom settings. Teachers were engaged in a critical dialogue in using these materials. Data supported four positive outcomes of the reflective model for teachers: enjoyment of collaborative engagement and reflective critical dialogue; development of curriculum materials aligned with teachers' collective classroom complexities and commonalities; positive effect of seeing and doing reflection in practice; and, positive student classroom outcomes.

With one successful technique of reflection, Ibrahim (2006) attempted to empower future teachers with reflective thinking and as he examined the effect of using portfolio -based instruction on pre-service EFL teachers' reflective thinking and teaching skills. Ibrahim concluded that subjects were trained reflectively surpassed their peers in both their teaching performance. He recommended that the activities carried out by student teachers should be carried out by student -teachers 
should be changed in that the learning experience becomes related to the actual teaching situations.

Rodgers (2006) highlighted that the power of students' descriptive feedback of their own learning, a process that is called "attending to students' voices". Descriptive feedback is a reflective conversation between teacher and students wherein students describe their experiences as learners within the large frame of reflective practice.

\section{Studied Related to Learning Autonomy:}

Orief (2018) conducted a study adopting the flipped approach through the use of videos on an EFL writing course and explored its impact on EFL learners' intrinsic motivation (IM) and learning outcomes. The present research was conducted with 55 female undergraduate EFL learners in the Kingdom of Saudi Arabia (KSA). Two writing classes were selected: one to receive flipped classroom teaching through the use of videos $(n=24)$ and the other, non-flipped teaching $(n=31)$. A positive correlation was found between IM and learning outcomes, and between learning outcomes and the supporting environment for the satisfaction of the above-mentioned psychological needs. In addition, from the qualitative data gathered, different types of support were found to be helpful for satisfying these psychological needs using the flipped approach.

Yurdakul (2017) concluded from his study investigating the relationship between autonomous learning and lifelong learning that autonomous learning has a positive interaction with lifelong learning which can be found voiced in one's ongoing, voluntary, and self-motivated learning.

Han (2014) presented a study focusing on the teacher's roles in fostering learner autonomy. The roles that teachers are expected to play from the theoretical and empirical backgrounds are reviewed and the future research trend was explained based on it. The study provided some implications for future research. English teachers' belief and roles they play in fostering learning Autonomy in their language classroom teaching. 
Borg \& Al-Busaidi (2012) conducted a study on learner autonomy and English teachers' beliefs. They sought to explore what learner autonomy means to teachers. Two strategies for data collection were used; a questionnaire and interviewing. The insights reported into language teachers' beliefs and reported practices regarding learner autonomy were a valuable addition to literature.

Brikena \& Gezim (2011) introduced a study to examine the techniques that can promote learner autonomy in a Higher Institution in Macedonia, South East European University in Tetovo. The study aimed to reveal learners' responsibility for their learning, and it showed that the use of different techniques can promote learner autonomy in Higher education in Macedonia.

Barmhal, Lewis, \& Norcliffe (2010) reported on strategic developments to enhance student learner autonomy skills through the use of enquiry-based learning (EBL) in the design of higher education programmes. The UK's Sheffield Hallam University is a recognized Centre of Excellence in Teaching and Learning (CETL) in the field of developing learner autonomy. Central to the university's learning, teaching and assessment strategy is the conviction that students must become autonomous learners to acquire the skills and knowledge needed for employment, research and continuing professional development.

\section{Conclusion:}

Based on reviewing literature, several studies had been conducted to investigate the impact of using flipped learning in developing learners' achievement, motivation, empowerment, and involvement and promoting students' higher thinking skills. However, to the knowledge of the researcher very few of these studies tried to investigate the impact of using it for enhancing student-teachers' reflective teaching skills .It was also concluded that there is a need for teachers who can think more systematically about their work and make their own beliefs about language learning and language teaching more explicitly. If 
reflection can help our understanding of how learning takes place, then it can help teachers guide their own development, so teachers can guide and change the direction of this process more easily. The best way for achieving this is by involving pre-service teachers in some kind of reflective activities achieved through flipped learning.

The researcher assumes that through flipped learning, learners would have the time to have exposure to the content prior to class thus lessens the dependence on the teacher to deliver the content. Class time will be devoted for learners to reflect on the material being presented and comment on their presentations as well as their peers' performance, solve problems, think deeply, involve in the learning process, work cooperatively with their peers as well as their instructor and reflect on their teaching practices.

Moreover, flipped learning can act as a powerful mean for enhancing students' learning autonomy which is considered by many researchers as a lifelong skill. Giving students the opportunity to search, work, analyze and think will surely reduce the over reliance on the teacher and expand the space within the curriculum.

\section{Context of the problem:}

Two hours aweek are assigned to micro-teaching sessions: one hour for theoretical teaching and another for training in stimulated classroom situations. These two hours, from the viewpoint of the researcher is not sufficient to develop students' reflective teaching skills. Therefore, the researcher sought to adopt the strategy of flipped learning in teaching the microteaching course as to provide students sufficient time to enhance and practice their reflective teaching skills as this strategy requires, as mentioned earlier, prior exposure to the content from the part of the learner . Moreover, several researchers such as (Yang 2017 and Matwejczyk \& Alexandar 2016) asserted that student teachers need crucial advanced strategies that move students onto more reflective practices. They need skills that help them promote analytical thinking and reflection. 
For this purpose, the researcher developed a needs assessment questionnaire for identifying:

1. How far do TEFL staff members estimate and adopt flipped learning in teaching their EFL course?

2. How far can the use of flipped learning develop students' reflective teaching skills?

3. How far can the use of flipped learning develop students' learning autonomy?

The questionnaire was administered to twelve TEFL staff members. The majority of them pointed to the following:

1. They did not try to teach their courses depending on flipped learning strategy.

2. They agreed that teaching EFL courses using the flipped learning strategy may develop students' reflective teaching skills.

3. They agreed that teaching EFL courses using the flipped learning strategy may develop students' learning autonomy.

\section{Statement of the problem:}

Based on the results obtained from the needs assessment questionnaire and the researcher's observation in the field of English language methodology, it was clear that the third year English majors need to enhance their reflective teaching skills and learning autonomy. The researcher assumed that by using flipped learning, students' reflective teaching skills and learning autonomy could be enhanced. Thus, the present study attempted to investigate the following:

"Using Flipped Learning for Enhancing Faculty of Education English Majors' Reflective Teaching Skills and Learning Autonomy"

\section{Purpose of the study:}

\section{The current study attempted to:}

1. identify the use of flipped learning for enhancing Faculty of Education English Majors' reflective teaching skills 
2. identify the use of flipped learning for enhancing Faculty of Education English Majors' learning autonomy.

\section{Questions of the Study:}

The current study was an attempt to answer the following questions:

1. How would flipped learning enhance Faculty of Education English Majors Reflective Teaching Skills?

2. How would flipped learning enhance Faculty of Education English Majors' learning Autonomy?

\section{Hypotheses of the Study:}

In the light of the literature review and the results of the needs assessment questionnaire the following hypotheses were tested:

1. There would be a statistically significant difference between the mean score of the treatment and the non treatment groups (favoring the treatment group) in the post-performance of the reflective teaching skills test.

2. There would be a significant a statistically significant difference between the mean score of the treatment and the non- treatment group (favoring the treatment group) in the post administration of the learning autonomy scale.

\section{Significance of the Study:}

The importance of the current study emerged from the following points:

1. The present study tried to fill the gap in the review of literature about studies that dealt with using flipped learning strategies in developing students' reflective teaching skills and learning autonomy.

2. The present study offers a teacher's guide which is basically designed in the light of the flipped learning strategy for enhancing students' reflective teaching skills and learning autonomy.

3. The present study offered a reflective teaching skills test.

4. The current study offered a learning autonomy scale. 
5. The study highlighted the importance of using some active learning strategies such as workshops, brainstorming, discussions, and debates, think pair share for promoting students' reflective teaching skills.

6. The study offered a reflection log where students had the chance to answer some reflective questions proposed after each session.

7. The study offered students a closed grouped labeled "Lets Flip our Classroom" where students had the chance to receive YouTube videos and Power Point Presentations about the material to view at home giving them enough opportunity to reflect on the material they had to discuss in class. Students also where asked to comment and reflect on these videos and they had the chance to share any relevant videos related to the topic under discussion.

\section{Delimitations of the Study:}

1. The study was delimitated to third year English Majors because they have considerable knowledge in methodology and sufficient opportunities to apply their reflective teaching skills in their teaching practice in third year and upwards.

2. The teaching skills of "Becoming aware of thinking process", "comprehending", "comparing", "analyzing", "planning", "brainstorming ideas", "developing hypotheses", "establishing cause and effect", "organizing thoughts and ideas", "forming an opinion", "decisionmaking", "creating", "problem solving", "evaluating" and "providing feedback".

3. The study was implemented in the "Micro-teaching" course in the second semester of the academic year 20172018.

\section{Definitions of terms:}

\section{Flipped Learning:}

Flipped learning is an instructional strategy and a type of blended learning that reverses the traditional educational 
arrangement by delivering instructional content, often online, outside of the classroom. It moves activities, including those that may have traditionally been considered homework, into the classroom. In a flipped classroom, students watch online lectures, collaborate in online discussions, or carry out research at home and engage in concepts in the classroom with the guidance of the instructor. (Abeysekera \& Dawson, 2015).

Flipped learning is a pedagogical approach in which the conventional notion of classroom-based learning is inverted, so that students are introduced to the learning material before class, with classroom time then being used to deepen understanding through discussion with peers and problemsolving activities facilitated by teachers.( Flipped Learning Network FLN:2014)

The researcher operationally defined flipped learning in her study as the ability of the instructor to carefully design appropriate learning materials and appropriate well-selected You-tube videos and power point presentations which are previously posted to students on a certain platform such asFace book - to give students enough time for viewing the material before coming to class and then devoting classroom time for inclass activities for promoting students' generic skills, self-study, self-management, communication, collaboration and reflective abilities and practices.

\section{Reflective Teaching:}

Al-Ahdal et.al (2014)-citing Pennington - defined reflective teaching as a "Movement in teacher Education in which studentteachers or practicing teachers analyze their own practice and its underlying basis, and then consider alternative means for achieving their ends".

Serrra (2015) defined reflective teaching as personal and more systematic tool that teachers can use to observe the way they behave in their classroom. It can be both a private process as well as the one that is discussed with colleagues. It is about more than just summarizing that happened in the classroom. 
Kizlik (2005) gave the following prerequisites for reflective practices which would be adopted in the current study.

1. Thinking: refers to the process of creating a structured series of connective transactions between items of perceived information.

2. Thinking process: refers to cognitive operations such as concept formation and problem solving.

3. Creating: refers to the ability to form new combinations of ideas to fulfill a need or to get original or appropriate results by the criteria of the domain in question.

4. Analyzing: means clarifying existing information by examining parts and relationships.

5. Comprehending : means generating meaning or understanding by relating new information to prior knowledge.

6. Decision making: refers to the process of selecting from among alternatives.

7. Evaluating: means assessing the reasonableness and quality of ideas and assessing one's current knowledge state.

8. Organizing: can be defined as arranging information so that it can be used more effectively.

9. Planning: refers to the process of developing strategies to reach a specific goal.

10. Problem solving: means analyzing a perplexing or difficult situation for the purpose of generating a solution.

In addition to adopting Kiziliks' skills, the researcher could define Reflective teaching as the ability of student teachers to collect data about teaching, examine their attitudes, beliefs, assumptions and teaching practices and use the information obtained as a basis for critical reflection about teaching.

\section{Learning Autonomy:}

Holec (1981) defined "Learner autonomy " as " the ability to take charge of one's own learning". 
It was also defined by Panton (1999) as "The characteristic of the person who independently exhibits agency in learning activities".

Little (2000) combined Holec's definition with his own "Autonomy in Language Learning depends on the development and exercise of a capacity for detachment, critical reflection, decision making and independent action; autonomous learners assume responsibility for determining the purpose, content, rhythm and method of learning; monitoring its progress and evaluating its outcome".

The researcher operationally defined learning autonomy " as the learners' ability to have independence in their learning, to possess self-management to make the highest potential use of their study habits and to show high rates in their desire of learning".

\section{Method}

\section{Design:}

A pre-post quasi experimental design was adopted in the present study. The treatment and the non-treatment groups were exposed to pre-post means of collecting data. The treatment group was taught the micro teaching course using the flipped learning strategy whereas the non-treatment group received the conventional way of instruction.

\section{Participants:}

Seventy students were randomly divided into two groups; a treatment group and a non-treatment one. They were selected from among third year English majors at the Faculty of Education, Minia University. Each group consisted of thirty five students. In order to make sure of their equivalence, the researcher administered a language proficiency exam (EPE). Table (1) shows no significant difference between the two groups as t-value is (0.383) that is not significant at 0.05 . 
Table (1):Means, Standard Deviations and t-value of Participants' Language Proficiency

\begin{tabular}{|l|l|l|l|l|l|l|l|}
\hline Variable & Group & $\mathrm{N}$ & Mean & $\begin{array}{l}\text { Std. } \\
\text { Deviation }\end{array}$ & 't' & D.F & $\begin{array}{l}\text { Sig. (2- } \\
\text { tailed) }\end{array}$ \\
\hline $\begin{array}{l}\text { Language } \\
\text { Proficiency } \\
\text { Level }\end{array}$ & $\begin{array}{l}\text { Non- } \\
\text { Treatment }\end{array}$ & 35 & $\mathbf{4 2 . 6 5 7 1}$ & $\mathbf{4 . 9 3 4 5 3}$ & $* 0.383$ & 68 & $\mathbf{0 . 7 0 3}$ \\
\cline { 2 - 5 } & Treatment & 35 & $\mathbf{4 3 . 1 4 2 9}$ & $\mathbf{5 . 6 4 7 1 9}$ & & \\
\hline
\end{tabular}

*Not Significant at 0.05 level

The Main Features of the Flipped Learning Teacher's Guide (See appendix A):

1. The teacher's guide began with an introduction about the main objective of the teacher's guide, its components, and importance.

2. The teacher's guide included a set of ILOs that mainly aimed to enhance students' reflective teaching skills and learning autonomy.

3. The researcher reformulated the content of the micro teaching course in order to be compatible with the flipped learning strategy.

4. Eleven sessions were introduced.

5. In-class and out class activities were specified

6. Evaluation techniques were determined to be online as well as in-class

7. The researcher attached to the teacher's guide a reflection $\log$ as students were encouraged to answer reflective questions.

8. The researcher also attached an observation sheet by which students could assess their own performance and their peers' performance as well.

\section{The Treatment group:}

The treatment group was taught the microteaching course in the light of the flipped learning strategy. The researcher provided an orientation session to the participants about the 'What', the 'Why', and the 'How' of flipping EFL classrooms. The researcher launched a Facebook closed group " Lets Flip our Classroom" and told the participants about it. They all liked and 
admired the idea and soon became frequent visitors. Using this closed group, participants could preview and make use of YouTube videos or PowerPoint presentations about the prescribed sessions before entering the classroom. Thus, they had time to view, post, discuss, comment and share their presentations in the course and their presentations in their teaching practice with their peers. Participants had to answer online activities and assignments. Moreover, viewing the content online made participants ready for classroom discussion with the instructor.

In-class sessions, participants were divided into seven groups: five participants each. Each group chose a 'name' that was used all the course long. The Classroom time was totally devoted to in-class activities such as brainstorming, Think-PareShare, Workshops, debates, discussions, mini-lectures and demonstrations. Students used the reflection log for answering reflective questions within and after the session. All students were asked to present micro lessons and were assessed using the observation checklist by which they had the opportunity to foster their reflective teaching skills. In addition, participants were also asked to prepare teaching aids, portfolios with a glossary and diaries. Photos of participants while practicing inclass activities, their presentations and their comments about the course were uploaded onto their assigned Facebook group.

\section{Instructors:}

The researcher taught the treatment group using flipped learning whereas the non- treatment group was taught the same content by another colleague with approximately the same experience and the same qualifications using the conventional way of instruction.

\section{Instruments: (For more details see appendix B)}

The researcher developed the following instruments

1. A needs Assessment questionnaire for assessing staff members' use of flipped instruction in TEFL.

2. The reflective teaching skills inventory. 
3. A reflective teaching Skills Test.

4. A Learning Autonomy Scale.

\section{Construction of the Needs Assessment Questionnaire:}

The researcher designed a needs assessment questionnaire for assessing TEFL staff member's use of the flipped learning in TEFL.

\section{The purpose of the questionnaire was to assess:}

1. How far do TEFL staff members estimate and adopt the flipped learning in their teaching practices?

2. How far can the use of flipped learning enhance students' reflective teaching skills?

3. How far can the use of flipped learning enhance students' learning autonomy?

\section{The questionnaire consists of seventeen statements distributed under three main domains:}

1. Using flipped learning in TEFL sessions.

2. Using flipped learning for enhancing students' reflective teaching skills.

3. Using flipped learning for enhancing students' learning autonomy.

After administering the needs assessment questionnaire on twelve TEFL staff members, results revealed that:

1. The twelve members have not tried yet to use the flipped learning in teaching their courses.

2. Using flipped learning can enhance students' reflective teaching skills.

3. Using flipped learning can enhance students' learning autonomy.

\section{Construction of the reflective teaching skills} inventory :

1. The researcher prepared a preliminary list of the reflective teaching skills that had been selected through reviewing the related literature. 
2. The list included 19 sub-skills.

3. The preliminary list was submitted to a jury of nine TEFL staff members. They were asked to decide which of those skills are mostly important to the target participants.

4. Most of the jury members recommended the omission of "Developing trial and error-constructing argumentsMatching- Following instructions step by step"

5. Most of the jury members approved the following reflective teaching sub-skills (Becoming aware of thinking process, comprehending, comparing, analyzing, planning, brainstorming ideas, developing hypotheses, establishing cause and effect, organizing thoughts and ideas, forming an opinion, decision- making, creating, problem solving, evaluating and providing feedback).

\section{Construction of the Reflective Teaching Skills Test:}

After submitting the reflecting teaching skills inventory and after reviewing literature on the construction of reflective teaching skills test especially the studies conducted by (Sonia 2010, Awad 2009 and Ibrahim 2006). The reflective teaching skills test of the current study was developed. The test consisted of twenty -five items covering different topics in teaching, questions and problems covering the selected fifteen reflective teaching skills.

The researcher prepared a "Table of Specifications" for the test of the reflective teaching skills" . (See appendix B)

\section{Test Objective:}

The objective of the test was to measure Faculty of Education Third year English majors' reflective teaching skills.

\section{Item Type:}

The test included twenty five problems; ten questions were of the multiple choices with three alternatives. The student teachers were asked to choose the best answer and provide their rationale for their choice. The other questions are open ended questions that assess the student teachers' reflective teaching 
skills. They really required real reflections that need descriptive, conceptual, and contemplations.

\section{Scoring:}

Four points were given for each correct choice with logical reasons or the rationale for the choice or the correct answer of the open ended questions. The correct answers of the test were judged by a jury (of five members) of TEFL specialists. That was because most of the items of the test have suggested and anticipated answers. All the jury members approved the answers of the test and confirmed their correctness.

\section{Time of Test Administration:}

Time allowed to complete the test was calculated during the pilot study which was conducted five weeks prior to the experimentation. The time taken by the first student teacher finishing the test plus the time taken by the last one, divided by two. The average was found to be two hours.

\section{Difficulty coefficient:}

Analysis of the responses to individual items was calculated to determine item difficulty for the test. The difficulty of the items is understood as the proportion of the persons who answer a test item correctly. The coefficient of difficulty ranged from (0.31) to (0.75).

\section{Discriminating Power:}

To determine item discriminating power, the researcher used eleven answer sheets with the highest scores for the upper group, and eleven answer sheets with the lowest scores for the lower group. Computing the responses to each item by the upper group and the lower group revealed that the discrimination power of the test ranged from $(0.25)$ to $(0.75)$

\section{Validity of the Reflective Teaching Skills Test:}

\section{Content Validity:}

To establish the content validity of the test, the test with its table of specifications was distributed to nine TEFL Staff 
members. The members were asked to evaluate it in terms of; linguistic stating of items, academic verifications of the content, whether the items measure how far the objectives have been achieved, and coverage of the number of the items for the skills depicted in the test and applicability of the test. The nine jury members' suggestions were taken into consideration. They confirmed its suitability and applicability.

\section{Test Internal Consistency:}

To calculate the internal consistency index of the test, the researcher used the correlation coefficients. The average coefficient for the whole test is (0.77). Each reflective teaching sub-skill has its internal consistency index which ranged from $(0.62)$ to (0.73) and was found acceptable. Table (2) presents a summary of these results.

Table ( 2 ):The Internal Consistency Coefficients of the Test of the Reflective Teaching Skills

\begin{tabular}{|l|l|l|}
\hline No & Reflective Teaching Skills & Validity \\
\hline $\mathbf{1}$ & Becoming Aware of thinking processes & ${ }^{*} \mathbf{0 . 6 2}$ \\
\hline $\mathbf{2}$ & Comprehending & ${ }^{*} \mathbf{0 . 6 5}$ \\
\hline $\mathbf{3}$ & Comparing & ${ }^{*} 0.63$ \\
\hline $\mathbf{4}$ & Analyzing & ${ }^{*} \mathbf{0 . 6 6}$ \\
\hline $\mathbf{5}$ & Establishing Cause and Effect & ${ }^{*} \mathbf{0 . 6 4}$ \\
\hline $\mathbf{6}$ & Evaluating & ${ }^{*} 0.64$ \\
\hline $\mathbf{7}$ & Creating & ${ }^{*} \mathbf{0 . 7 2}$ \\
\hline $\mathbf{8}$ & Brainstorming Ideas & ${ }^{*} \mathbf{0 . 7 3}$ \\
\hline $\mathbf{9}$ & Organizing Thoughts and Ideas & ${ }^{*} 0.67$ \\
\hline $\mathbf{1 0}$ & Forming an opinion & ${ }^{*} \mathbf{0 . 6 9}$ \\
\hline $\mathbf{1 1}$ & Developing Hypotheses & ${ }^{0.70}$ \\
\hline $\mathbf{1 2}$ & Planning & ${ }^{*} 0.65$ \\
\hline $\mathbf{1 3}$ & Decision-making & ${ }^{*} \mathbf{0 . 6 7}$ \\
\hline $\mathbf{1 4}$ & Problem solving & ${ }^{*} \mathbf{0 . 6 5}$ \\
\hline $\mathbf{1 5}$ & Providing Feedback & ${ }^{*} 0.64$ \\
\hline $\mathbf{1 6}$ & The whole test & ${ }^{0} \mathbf{0 . 6 2}$ \\
\hline & *Significant at 0.05 level and beyond & \\
\hline
\end{tabular}

\section{Test Reliability:}

In order to establish the reliability of the reflective teaching skills test, it was administered to a randomly chosen sample of third year English majors $(\mathrm{N}=30)$. The pilot study was conducted 
at the end of the first term. The reliability of the test was determined by using test-retest method. The researcher and another TEFL Staff member marked the test because of the items of the test have suggested and anticipated answers. The average score of every student teacher was calculated. The whole test has a reliability coefficient of (0.84) and was found acceptable.

Table (3):The Reliability of Each Sub-Skill in the Reflective Teaching Skills Test

\begin{tabular}{|c|c|c|}
\hline No & Reflective Teaching Sub-Skills & $\begin{array}{l}\text { Reliability } \\
\text { Coefficient }\end{array}$ \\
\hline $\mathbf{1}$ & Becoming Aware of thinking processes & ${ }^{*} \mathbf{0 . 8 3}$ \\
\hline 2 & Comprehending & $* 0.88$ \\
\hline 3 & Comparing & $* 0.69$ \\
\hline 4 & Analyzing & $* \mathbf{0 . 8 0}$ \\
\hline 5 & Establishing Cause and Effect & $* 0.64$ \\
\hline 6 & Evaluating & $* 0.77$ \\
\hline 7 & Creating & $* 0.75$ \\
\hline 8 & Brainstorming Ideas & ${ }^{*} \mathbf{0 . 8 2}$ \\
\hline 9 & Organizing Thoughts and Ideas & ${ }^{*} \mathbf{0 . 8 0}$ \\
\hline 10 & Forming an opinion & $* 0.65$ \\
\hline 11 & Developing Hypotheses & $* 0.87$ \\
\hline 12 & Planning & ${ }^{*} 0.66$ \\
\hline 13 & Decision-making & $* 0.68$ \\
\hline 14 & Problem solving & $* 0.82$ \\
\hline 15 & Providing Feedback & $* 0.66$ \\
\hline 16 & The whole test & $* 0.84$ \\
\hline
\end{tabular}

*Significant at 0.05 level and beyond

\section{Construction of the Learning Autonomy Scale:}

The researcher reviewed literature on the construction learning autonomy scales such as the studies conducted by (Yurkdaul 2017; Morgan (2015); Merc (2015) and Benson (2011))

1. The scale composed of forty items covering four domains. Each domain consisted of ten statements. The domains were as follow:

1. Independence of learning.

2. Self-Management.

3. Desire for Learning

4. Study habits. 
2. The scale was a 5 point-Likert scale.

\section{Objective of the Scale:}

The main objective of the scale was to assess how far third year English majors are autonomous learners.

\section{Time Allotted:}

Forty five minutes were assigned for responding to the learning autonomy scale.

\section{The Scale Validity:}

\section{The content validity of the Scale:}

1. The content validity of the scale was decided through submitting the learning autonomy scale to a nine TEFL experts to establish its validity with regard to : The belongingness of the sub-domains to the main domain, the importance of the sub-domains to be measured, linguistic stating of the statements included, the suitability of the statements for the participants (Third year English majors), applicability and relatedness of the statements to the objectives of the study and if there any suggestions , addition or omission .

2. The jury members confirmed the suitability of the scale as it would help to assess students' learning autonomy. They stated that the items were inclusive, easy to respond, varied and focused.

\section{Internal Consistency of the Scale:}

The Pearson correlation formula was used to determine the internal consistency of the learning autonomy scale. It was applied to a randomly chosen sample of thirty $(\mathrm{N}=30)$ third year English majors. The correlation between the different domains and the total scale was determined as shown in table (4) below and was found acceptable. 
Table (4) Internal Consistency of the Learning Autonomy Scale Correlation between Each Domain and the Total Scale

\begin{tabular}{|l|l|}
\hline Learning Autonomy & Correlation \\
\hline Independence of Learning & ${ }^{*} \mathbf{0 . 8 3}$ \\
\hline Self-management & ${ }^{*} \mathbf{0 . 9 4}$ \\
\hline Desire for Learning & ${ }^{*} \mathbf{0 . 8 7}$ \\
\hline Study habits & ${ }^{*} \mathbf{0 . 8 7}$ \\
\hline
\end{tabular}

*Significant at 0.05 level and beyond

The correlation between each statement and the total scale was determined as shown in table (5) and was also found acceptable.

Table (5) Internal Consistency of the Learning Autonomy scale Correlation between Each Statement and the Total Scale

\begin{tabular}{|c|c|c|c|}
\hline No. & Correlation & No. & Correlation \\
\hline 1 & $* 0.73$ & 21 & $* 0.75$ \\
\hline 2 & $* 0.64$ & 22 & *0.71 \\
\hline 3 & $* 0.63$ & 23 & $* 0.74$ \\
\hline 4 & $*^{*} 0.73$ & 24 & $*^{*} \mathbf{0 . 8 1}$ \\
\hline 5 & $* 0.77$ & 25 & $* 0.73$ \\
\hline 6 & $* 0.75$ & 26 & $* 0.70$ \\
\hline 7 & $* 0.64$ & 27 & *0.71 \\
\hline 8 & $* 0.63$ & 28 & $* 0.80$ \\
\hline 9 & ${ }^{*} 0.73$ & 29 & ${ }^{*} \mathbf{0 . 8 0}$ \\
\hline 10 & *0.71 & 30 & $* 0.74$ \\
\hline 11 & *0.87 & 31 & *0.70 \\
\hline 12 & $* 0.74$ & 32 & $* 0.67$ \\
\hline 13 & $* 0.74$ & 33 & ${ }^{*} \mathbf{0 . 8 4}$ \\
\hline 14 & $* 0.72$ & 34 & $* 0.76$ \\
\hline 15 & $* 0.76$ & 35 & $* 0.64$ \\
\hline 16 & $* 0.84$ & 36 & $* 0.65$ \\
\hline 17 & $* 0.70$ & 37 & ${ }^{*} \mathbf{0 . 8 1}$ \\
\hline 18 & *0.69 & 38 & $* 0.64$ \\
\hline 19 & $* 0.88$ & 39 & $* 0.70$ \\
\hline 20 & $*_{0.71}$ & 40 & *0.71 \\
\hline
\end{tabular}

*Significant at 0.05 and beyond

The correlation between the four domains and their statements was also calculated as shown in table (6) and was found acceptable. 
Table (6) Internal Consistency of the Learning Autonomy scale

Correlation between Statements and the Total of their Domains

\begin{tabular}{|c|c|c|c|c|c|c|c|}
\hline \multicolumn{2}{|c|}{$\begin{array}{l}\text { Independence of } \\
\text { Learning }\end{array}$} & \multicolumn{2}{|c|}{$\begin{array}{l}\text { Self- } \\
\text { Management }\end{array}$} & \multicolumn{2}{|c|}{$\begin{array}{ll}\text { Desire } & \text { for } \\
\text { Learning } & \end{array}$} & \multicolumn{2}{|c|}{ Study Habits } \\
\hline No. & $\begin{array}{l}\text { Correlatio } \\
\text { n }\end{array}$ & No. & $\begin{array}{l}\text { Correla } \\
\text { tion }\end{array}$ & No. & $\begin{array}{l}\text { Correla } \\
\text { tion }\end{array}$ & No. & $\begin{array}{l}\text { Correla } \\
\text { tion }\end{array}$ \\
\hline $\begin{array}{l}\text { Item } \\
1\end{array}$ & $* 0.80$ & $\begin{array}{l}\text { item } \\
11\end{array}$ & $* 0.92$ & $\begin{array}{l}\text { Item } \\
21\end{array}$ & ${ }^{*} 0.86$ & $\begin{array}{l}\text { Item } \\
31\end{array}$ & $* 0.78$ \\
\hline $\begin{array}{l}\text { Item } \\
2\end{array}$ & $* 0.79$ & $\begin{array}{l}\text { item } \\
12\end{array}$ & $* 0.80$ & $\begin{array}{l}\text { Item } \\
22\end{array}$ & ${ }^{*} 0.82$ & $\begin{array}{l}\text { Item } \\
32\end{array}$ & $* 0.87$ \\
\hline $\begin{array}{l}\text { Item } \\
3\end{array}$ & $*^{*} 0.84$ & $\begin{array}{l}\text { item } \\
13\end{array}$ & $* 0.80$ & $\begin{array}{l}\text { Item } \\
23\end{array}$ & $* 0.86$ & $\begin{array}{l}\text { Item } \\
33\end{array}$ & $* 0.80$ \\
\hline $\begin{array}{l}\text { Item } \\
4\end{array}$ & ${ }^{*} 0.76$ & $\begin{array}{l}\text { item } \\
14\end{array}$ & ${ }^{*} \mathbf{0 . 7 7}$ & $\begin{array}{l}\text { Item } \\
24\end{array}$ & ${ }^{*} 0.96$ & $\begin{array}{l}\text { Item } \\
\mathbf{3 4}\end{array}$ & ${ }^{*} \mathbf{0 . 8 7}$ \\
\hline $\begin{array}{l}\text { Item } \\
5\end{array}$ & ${ }^{*} 0.78$ & $\begin{array}{l}\text { Item } \\
15\end{array}$ & ${ }^{*} 0.86$ & $\begin{array}{l}\text { Item } \\
25\end{array}$ & $* 0.81$ & $\begin{array}{l}\text { Item } \\
35\end{array}$ & $* 0.77$ \\
\hline $\begin{array}{l}\text { Item } \\
6\end{array}$ & ${ }^{*} \mathbf{0 . 8 0}$ & $\begin{array}{l}\text { Item } \\
16\end{array}$ & ${ }^{*} 0.85$ & $\begin{array}{l}\text { Item } \\
26\end{array}$ & ${ }^{*} 0.84$ & $\begin{array}{l}\text { Item } \\
36\end{array}$ & ${ }^{*} 0.85$ \\
\hline $\begin{array}{l}\text { Item } \\
7\end{array}$ & ${ }^{*} \mathbf{0 . 8 9}$ & $\begin{array}{l}\text { Item } \\
17\end{array}$ & ${ }^{*} \mathbf{0 . 7 8}$ & $\begin{array}{l}\text { Item } \\
27\end{array}$ & $* 0.77$ & $\begin{array}{l}\text { Item } \\
\mathbf{3 7}\end{array}$ & ${ }^{*} \mathbf{0 . 7 9}$ \\
\hline $\begin{array}{l}\text { Item } \\
8\end{array}$ & $* 0.88$ & $\begin{array}{l}\text { Item } \\
18\end{array}$ & $* 0.73$ & $\begin{array}{l}\text { Item } \\
28\end{array}$ & $* 0.83$ & $\begin{array}{l}\text { Item } \\
\mathbf{3 8}\end{array}$ & $* 0.78$ \\
\hline $\begin{array}{l}\text { Item } \\
9\end{array}$ & ${ }^{*} 0.93$ & $\begin{array}{l}\text { Item } \\
19\end{array}$ & ${ }^{*} 0.93$ & $\begin{array}{l}\text { Item } \\
29\end{array}$ & ${ }^{*} 0.96$ & $\begin{array}{l}\text { Item } \\
39\end{array}$ & ${ }^{*} \mathbf{0 . 8 9}$ \\
\hline $\begin{array}{l}\text { Item } \\
10\end{array}$ & $*^{*} \mathbf{0 . 8 9}$ & $\begin{array}{l}\text { Item } \\
20\end{array}$ & ${ }^{*} \mathbf{0 . 7 0}$ & $\begin{array}{l}\text { Item } \\
\mathbf{3 0}\end{array}$ & ${ }^{*} 0.93$ & $\begin{array}{l}\text { Item } \\
40\end{array}$ & ${ }^{*} 0.74$ \\
\hline
\end{tabular}

*Significant at 0.05 and beyond

\section{Reliability of the learning Autonomy scale:}

Estimating the reliability of the scale was done four weeks prior to the administration of the treatment. Thirty $(\mathrm{N}=30)$ third year English majors were selected randomly to respond to the learning autonomy scale. Alpha Cronbach 's coefficient was used to check the reliability of the scale. The reliability coefficient reached (0.98) which was considered acceptable as shown in table (7). 
Table (7): The Cronbach Alpha's Reliability Coefficient of the Learning Autonomy Scale.

\begin{tabular}{|c|c|c|c|c|c|}
\hline Nc & Learning Autonomy & Mean & $\begin{array}{l}\text { Varianc } \\
\text { e }\end{array}$ & $\begin{array}{l}\text { Std. } \\
\text { Deviatio }\end{array}$ & $\begin{array}{l}\text { Cronbach' } \\
\text { s Alpha }\end{array}$ \\
\hline $\mathbf{1}$ & $\begin{array}{ll}\text { Independence } \\
\text { Learning }\end{array}$ & 35.10 & 129.96 & 11.40 & ${ }^{*} 0.95$ \\
\hline 2 & Self-Management & 34.00 & 79.59 & 8.92 & $* 0.94$ \\
\hline 3 & Desire for Learning & 36.50 & 79.98 & 8.94 & $* 0.96$ \\
\hline 4 & Study Habits & 36.60 & 69.77 & 8.35 & $*^{*} 0.94$ \\
\hline \multicolumn{2}{|c|}{ Total } & $\begin{array}{l}142.2 \\
0\end{array}$ & $\begin{array}{l}1081.2 \\
0\end{array}$ & 32.88 & $*^{*} 0.98$ \\
\hline
\end{tabular}

*Significant at 0.05 and beyond

\section{Findings, Discussion, Implications and Recommendations}

\section{Findings:}

\section{Testing hypothesis (1):}

Hypothesis (1) predicted that there would be a statistically significant difference between the mean score of the treatment and the non -treatment groups (favoring the treatment group) in the post-performance of the reflective teaching skills test.

Statistical analysis showed that this hypothesis was accepted as ' $t$ ' value (19.18) is significant at (0.01) favoring the treatment group .The effect size was calculated by Eta-square $\left(\eta^{2}\right)$ reached (0.92) as shown in table (10) and this value according to Nassar (2006) is of a high significance. Nassar(2006) mentioned that when Eta-squared value $\left(\eta^{2}\right)$ is less than 0.1 it means that the significance is weak, when $\left(\eta^{2}\right)$ is more than 0.1 and less than 0.6 this means the significance is medium, and when $\left(\eta^{2}\right)$ is more than 0.6 it means the significance is high. 
Table ( 8 ):Means, Standard Deviation, 't'-value and Eta-squared Value Obtained by the Treatment and the Non-treatment Groups on the Post-Performance of the Reflective Teaching Skills Test

\begin{tabular}{|l|l|l|l|l|l|l|l|l|}
\hline Test & Group & $\mathrm{N}$ & Mean & $\begin{array}{l}\text { Std. } \\
\text { Deviation }\end{array}$ & 't'-value & D.F & $\begin{array}{l}\text { Sig. } \\
\text { tailed) }\end{array}$ & $\begin{array}{l}\text { Eta- } \\
\text { square } \\
\text { d value }\end{array}$ \\
\hline $\begin{array}{l}\text { Reflective } \\
\text { Teaching }\end{array}$ & $\begin{array}{l}\text { Non- } \\
\text { Treat } \\
\text { ment }\end{array}$ & 35 & 35.2240 & 9.18549 & $* 19.18$ & 68 & 0.000 & 0.92 \\
\cline { 2 - 9 } & $\begin{array}{l}\text { Treat } \\
\text { ment }\end{array}$ & 35 & 68.1143 & 4.30776 & & & & \\
\hline
\end{tabular}

* Significant at 0.01

The Total score of the test $=100$

Table (9):Means, Standard Deviation, 't'-Value and Eta-squared Value Obtained by the Treatment and the Non-treatment groups on the Post-Performance of the Reflective Teaching Skills Test on each Sub-skill

\begin{tabular}{|c|c|c|c|c|c|c|c|c|}
\hline $\begin{array}{l}\text { Reflective } \\
\text { Teaching } \\
\text { skills }\end{array}$ & Group & $\mathbf{N}$ & Mean & $\begin{array}{l}\text { Std. } \\
\text { Deviation }\end{array}$ & 't' & D.F & $\begin{array}{l}\text { Sig. (2- } \\
\text { tailed) }\end{array}$ & $\begin{array}{l}\text { Eta- } \\
\text { squared } \\
\text { Value }\end{array}$ \\
\hline \multirow{2}{*}{$\begin{array}{l}\text { Becoming Aware } \\
\text { of the } \\
\text { Process }\end{array}$} & Non-treatment & 35 & 7.6857 & 3.08480 & \multirow[t]{2}{*}{$* 12.243$} & \multirow[t]{2}{*}{68} & \multirow[t]{2}{*}{0.000} & \multirow[t]{2}{*}{0.69} \\
\hline & Treatment & 35 & 15.0571 & 1.78132 & & & & \\
\hline \multirow[t]{2}{*}{ Comprehending } & Non-treatment & 35 & 6.2571 & 3.14683 & \multirow[t]{2}{*}{ *14.084 } & \multirow[t]{2}{*}{68} & \multirow[t]{2}{*}{0.000} & \multirow[t]{2}{*}{0.74} \\
\hline & Treatment & 35 & 14.4571 & 1.40048 & & & & \\
\hline \multirow[t]{2}{*}{ Comparing } & Non-treatment & 35 & 8.4286 & 2.64893 & \multirow[t]{2}{*}{ *10.428 } & \multirow[t]{2}{*}{68} & \multirow[t]{2}{*}{0.000} & \multirow[t]{2}{*}{0.62} \\
\hline & Treatment & 35 & 13.9143 & 1.63368 & & & & \\
\hline \multirow[t]{2}{*}{ Analyzing } & Non-treatment & 35 & 6.2286 & 3.17236 & \multirow[t]{2}{*}{ *14.038 } & \multirow[t]{2}{*}{68} & \multirow[t]{2}{*}{0.000} & \multirow[t]{2}{*}{0.74} \\
\hline & Treatment & 35 & 14.4571 & 1.40048 & & & & \\
\hline \multirow{2}{*}{$\begin{array}{l}\text { Establishing Cause } \\
\text { \& Effects }\end{array}$} & Non-treatment & 35 & 5.6857 & 2.44674 & \multirow[t]{2}{*}{ *10.079 } & \multirow[t]{2}{*}{68} & \multirow[t]{2}{*}{0.000} & \multirow[t]{2}{*}{0.60} \\
\hline & Treatment & 35 & 11.1714 & 2.09321 & & & & \\
\hline \multirow[t]{2}{*}{ Evaluating } & Non-treatment & 35 & 5.4571 & 2.57068 & \multirow[t]{2}{*}{ *11.376 } & \multirow[t]{2}{*}{68} & \multirow[t]{2}{*}{0.000} & 0.66 \\
\hline & Treatment & 35 & 11.9143 & 2.16077 & & & & \\
\hline Creating & Non-treatment & 35 & 8.2571 & 2.85269 & *6.386 & 68 & 0.000 & 0.37 \\
\hline & Treatment & 35 & 11.8000 & 1.62336 & & & & \\
\hline Brainstorming & Non-treatment & 35 & 6.7429 & 2.45360 & *14.949 & 68 & 0.000 & 0.77 \\
\hline & Treatment & 35 & 15.4000 & 2.39116 & & & & \\
\hline Organizing & Non-treatment & 35 & 8.9143 & 2.63875 & *9.889 & 68 & 0.000 & 0.59 \\
\hline & Treatment & 35 & 14.3429 & 1.89338 & & & & \\
\hline Forming & Non-treatment & 35 & 7.2571 & 2.84236 & ${ }^{* 8.303}$ & 68 & 0.000 & 0.50 \\
\hline Opinion & Treatment & 35 & 11.9714 & 1.79026 & & & & \\
\hline Developing & Non-treatment & 35 & 5.3143 & 2.71999 & *11.198 & 68 & 0.000 & 0.65 \\
\hline Hypotheses & Treatment & 35 & 11.7714 & 2.05921 & & & & \\
\hline Planning & Non-treatment & 35 & 6.3429 & 2.58892 & *15.206 & 68 & 0.000 & 0.77 \\
\hline & Treatment & 35 & 14.6571 & 1.93942 & & & & \\
\hline Decision Making & Non-treatment & 35 & 7.0286 & 3.29425 & *9.437 & 68 & 0.000 & 0.57 \\
\hline & Treatment & 35 & 12.9714 & 1.74028 & & & & \\
\hline Problem Solving & Non-treatment & 35 & 7.2000 & 2.70946 & *12.337 & 68 & 0.000 & 0.69 \\
\hline & Treatment & 35 & 13.9429 & 1.76473 & & & & \\
\hline Providing & Non-treatment & 35 & 8.6000 & 2.95257 & $*_{11.956}$ & 68 & 0.000 & 0.68 \\
\hline Feedback & Treatment & 35 & 15.6857 & 1.89071 & & & & \\
\hline
\end{tabular}

*Significant at 0.01 


\section{Testing Hypothesis (2):}

Hypothesis (2) predicted that There would be a significant a statistically significant difference between the mean score of the treatment and the non- treatment group (favoring the treatment group) in the post administration of the learning autonomy scale.

Statistical analysis showed that this hypothesis was accepted as ' $t$ ' value is (12.07) and it is significant at (0.01) favoring the treatment group. Table (10) below shows the data obtained to test this hypothesis. The effect size was calculated by Eta-square $\left(\eta^{2}\right)$ and it reached (0.68) as shown in table (10) and this value according to Nassar (2006) is of a high significance.

Table (10)

Means, standard Deviation, 't'-value and Eta-squared Value obtained by the treatment and the Non-Treatment groups on the Post Administration of the Learning Autonomy Scale

\begin{tabular}{|c|c|c|c|c|c|c|c|c|}
\hline Learning Autonomy & Group & $\mathbf{N}$ & Mean & Std. Deviation & 't'-value & D.F & $\begin{array}{l}\text { Sig. } \quad(2- \\
\text { tailed) }\end{array}$ & $\begin{array}{l}\text { Eta- } \\
\text { Squared }\end{array}$ \\
\hline \multirow{2}{*}{$\begin{array}{l}\text { Independence of } \\
\text { Learning }\end{array}$} & $\begin{array}{l}\text { Non- } \\
\text { treatment }\end{array}$ & 35 & 30.4571 & 4.40149 & \multirow[t]{2}{*}{$* 15.39$} & \multirow[t]{2}{*}{68} & \multirow[t]{2}{*}{0.000} & \multirow[t]{2}{*}{0.78} \\
\hline & Treatment & 35 & 43.1714 & 2.12112 & & & & \\
\hline \multirow[t]{2}{*}{ Self-management } & $\begin{array}{l}\text { Non- } \\
\text { treatment }\end{array}$ & 35 & 30.2286 & 5.65210 & \multirow[t]{2}{*}{ *3.13 } & \multirow[t]{2}{*}{68} & \multirow[t]{2}{*}{0.003} & \multirow[t]{2}{*}{0.13} \\
\hline & Treatment & 35 & 34.0000 & 4.33861 & & & & \\
\hline \multirow[t]{2}{*}{ Desire for Learning } & $\begin{array}{l}\text { Non- } \\
\text { treatment }\end{array}$ & 35 & 28.8571 & 4.97726 & \multirow[t]{2}{*}{$* 17.73$} & \multirow[t]{2}{*}{68} & \multirow[t]{2}{*}{0.000} & \multirow[t]{2}{*}{0.82} \\
\hline & Treatment & 35 & 45.0857 & 2.13337 & & & & \\
\hline \multirow[t]{2}{*}{ Study habits } & $\begin{array}{l}\text { Non- } \\
\text { treatment }\end{array}$ & 35 & 32.5429 & 4.81018 & \multirow[t]{2}{*}{ *6.18 } & \multirow[t]{2}{*}{68} & \multirow[t]{2}{*}{0.000} & \multirow[t]{2}{*}{0.36} \\
\hline & Treatment & 35 & 38.4000 & 2.88199 & & & & \\
\hline \multirow[t]{2}{*}{ Total scale } & $\begin{array}{l}\text { Non- } \\
\text { treatment }\end{array}$ & 35 & 122.0857 & 16.84946 & \multirow[t]{2}{*}{ *12.07 } & \multirow[t]{2}{*}{68} & \multirow[t]{2}{*}{ *0.000 } & \multirow[t]{2}{*}{0.68} \\
\hline & Treatment & 35 & 160.6571 & 8.56100 & & & & \\
\hline
\end{tabular}

*Significant at 0.01 level and beyond

The total score of the scale $=200$

\section{Discussion:}

Hypothesis 1 predicted that there would be there would be a statistically significant difference between the mean score of the treatment and the non -treatment groups (favoring the 
treatment group) in the post-performance of the reflective teaching skills test. Statistical analysis showed that this hypothesis was accepted. The effect size was calculated using Eta- squared formula to guarantee the effectiveness of using flipped learning strategy in enhancing students' reflective teaching skills was not due to chance.

The study provided data on the positive impact of using flipped learning in higher education. The findings indicated that the use of flipped learning resulted in higher use of reflective teaching skills than the conventional way of instruction followed by the non- treatment group.

A close inspection of the data obtained in this study shows a remarkable improvement of the reflective teaching skills of participants of the treatment group. One justification for this might be due to the use of a well -planned flipped learning teacher's guide that actually helped third year English majors develop both reflective teaching skills and learning autonomy necessary to experience higher levels of success in their upcoming years.

Again, using flipped learning encouraged students' reflection and developed their reflective abilities because they had the chance to reflect on the connection between the course materials they prepared prior to the lessons and activities in classes.This conclusion comes in consistent with the studies conducted by Abdel-Fattah (2017), Al-Bassuony (2016), Ahmed (2016), James, Chin \& Williaams (2014), Vaughan (2014) ,Kiran (2014)and Roehl et.al (2013).

One more possible account for this improvement may be the well selection of the You-tube videos and PowerPoint presentations which students received on the Facebook closed group "Let' flip our Classroom " gave them the chance to grasp the material being presented and be ready for classroom discussions. Classroom time was totally devoted to reflective activities and workshops that actually generated intrinsic motivation in the 
subject area. Students were so impressed with the experience they have met in the course.

The reflective teaching techniques which were used in the study managed to raise students' reflective teaching skills especially the reflection log which was designed by the researcher as students were asked to answer reflective questions within and after each session. Students had the chance to give and receive feedback on their performance and on their peers' as well whether in class or on line on the assigned Facebook group.

Thus, giving learners the power to make their own decisions about learning rather than the instructor having all the control would definitely foster students' empowerment. This could be achieved when learners had the chance to discuss, ask and answer questions, apply, get feedback, negotiate. The use of videos and other prerecorded media puts lectures under the control of students: they can watch, rewind, and fast forward as needed.

By contrast, in a conventional lecture, students often tried to capture what was being said at the instant the instructor said it. They could not stop to reflect upon what was being said and they might miss significant points because they were busy grasping the instructor's words. (Vanghan 2014 , Honeycutt \& Warren 2014; Roehl et.al., 2013; Stayer 2012)

The value of a flipped class is in the purposing of class time into a workshop where students can inquire about lecture content, test their skills in applying knowledge, and interact with one another in hands- on activities. During class sessions, instructors function as coaches or advisors, encouraging students in individual inquiry and collaborative effort.

Results revealed that participants showed improvement in their reflective teaching skills as a result of using flipped learning and this could be clearly shown in table (9) . Values indicating the improvements of the reflective teaching skills were arranged in a descending order according to their effect size as follows; "planning","brainstorming ideas", "comprehending", " analyzing", 
"becoming aware of the thinking process", "problem solving" , "providing feedback", "evaluating", "developing hypotheses", "comparing","establishing cause and effect", "organizing", "forming opinion" " and " creating". Thus, learners had the upper hand in controlling their learning environment, which increased the effectiveness of both the learning and the teaching process.

Hypothesis 2 predicted that there would be a significant a statistically significant difference between the mean score of the treatment and the non- treatment group (favoring the treatment group) in the post administration of the learning autonomy scale. Statistical analysis showed that this hypothesis was accepted.

A careful inspection of the findings concerning the learning autonomy scale revealed that flipped learning managed to enhance students' learning autonomy as the treatment group surpassed their counterparts in the non- treatment group on the post-administration of the learning autonomy scale. For developing learning autonomy instructors should provide learning environments that require conscious awareness of the learning process which flipped learning had truly provided. A good support for this finding comes from Orief (2018), Yurdakul (2017) , Lin \& Chen (2016) and Sinclair (2002). Using flipped learning helped in raising students' desire for learning, independence for leaning, study habits and finally selfmanagement. These domains are arranged in a descending order according to their effect size.

As for enhancing students' 'desire for learning' results revealed that third year English majors' desire for learning has been greatly enhanced through the use of flipped learning.This conclusion finds support from Kettani (2014), Cara (2012), Brikena \& Gezim (2011) as they asserted that for learning autonomy to exist suitable conditions should be constructed .Devoting classroom time to in-class activities has greatly aroused students' interest and aspiration especially their participation in workshops which they liked most. Students were also asked to search for e- articles, PowerPoint presentations, You-tube videos that were closely related to the topic under 
discussion. Online and in-class activities greatly enhanced students' independence.

Students' Self - management had been enhanced this might indicate the contribution of using flipped learning. Morgan (2015) in his study about "The Difference between Autonomy and Self-Management" asserted that autonomy and self-management are two different concepts but they are starting to be interchangeably. Learning autonomy is promoted by, and in turns promotes, our intrinsic motivation and interest. This explains how learner's autonomy solves the problem of learner's motivation. In this respect, Moeller (2016) highlighted that autonomous learner's draw on their intrinsic motivation when they accept the responsibility for their own learning and bind themselves to develop the skills of reflective self-management in learning .Consequently, autonomous learners can efficiently apply the knowledge and skills acquired inside the classroom in the those situations occur outside their classrooms.

Results of the present study also revealed that third year English majors showed considerable improvement in their study habits this might be attributed to the use of the flipped learning as the researcher assumed. This is supported by Field (2007) who pointed out that for obtaining the 'know-how' is greatly essential for reflecting on the learning process and managing learning.

To conclude, this study acknowledged the use of flipped learning in enhancing third year English majors' reflective teaching skills and learning autonomy. However, unrestricted access to information, without proper guidance and feedback, can in fact inhibit learners from taking more responsibility (Murray, 1999).

\section{Examples of Students' Reflections on the Course:}

In the final session, the researcher addressed a final question to the students "Now, what is your opinion about the course? Did you find it interesting? What skills have you gained? 
How far you think yourself a reflective and a dependent teacher", the researcher felt impressed and had a great sense of achievement. The following are some of their reflections:

Student (1):" This course is more than interesting. Every session in this course added to my knowledge and to my dealing with every situation happens inside the class. I think the most interesting thing in this course was the use of flipped learning; I really enjoyed it too much. I gained many skills, in every lecture I learn something new. This course increased my self-confidence and gave me the chance to discover and practice my abilities, and let me know that I can be an independent and active learner".

Student (2): "The course was more than wonderful. You are a good lecturer, teacher, and a good listener. We learned a lot of things. It is my first time to use a reflection log which really aroused our thinking and interest. I adore the way you believe in your course"

Student (3):" The course was more than unique I enjoyed the workshops we applied in the sessions besides commenting online on our presentations, posting related YouTube videos. These things took the most of my attention and unique other things in the course that can't be counted."

Student (4): "This course was very interesting and helped us to plan for our lesson successfully and manage the classroom time appropriately. I liked the idea of having a group which we could discuss, ask and comment on our presentations".

Student (5): "Once I entered the course I had the sense that I would become confidant inside the classroom, my planning and presentations skills had been improved. I learnt lots of things that affected my classroom management especially those related to time management".

\section{Implications:}

It is clear from the above discussion that using flipped learning significantly enhanced English majors' reflective teaching skills and learning autonomy. However, the next step is 
for the instructor to successfully integrate technology with teaching any subject matter. Using technology will hopefully make learning enjoyable and give learners sufficient opportunities to become autonomous learners. In addition, the idea of flipping classroom may put the responsibilities of the learning process over students' shoulders paving the way for them to think, analyze, reflect on their teaching and finally become self-dependent teachers.

\section{Recommendations:}

EFL instructors are strongly advised to incorporate flipped learning in teaching microteaching courses and try to transfer this to the teaching of other courses. More attention should be given to the development of reflective teaching skills in the training programs for both in-service and pre-service teachers. However, literature on reflective teaching stresses that, giving feedback then re-teaching is the best way to demonstrate results in microteaching courses. Fostering learning autonomy should be one of the priorities in the teaching- learning process.

\section{References}

Abeysekera, L., \& Dawson, P. (2015). Motivation and cognitive load in the flipped classroom: definition, rationale and a call for research. Higher Education Research \& Development, 1-14.

Abdel-Fattah, S. (2017). The Effectiveness of Adopting Flipped Learning Approach in an Applied Linguistics Course for University Students. British Journal of English Linguistics Vol.5, No.1, Pp:32-43 (Feb, 2017

Ahmed, S. (2016). The Flipped classroom Model to develop Egyptian EFL Students' Listening Comprehension. English Language Teaching. 9(9):166.August 2016

Al-Bassuony, J. (2016). The Effectiveness of Flipped learning in Developing English Grammatical Performance of Underachieving Language Learners at Secondary Stage. International Journal of English Language Teaching . Vol.4, N.8, Pp:76-101(Sept.2016) 
Al-Ahdal,A. \&Abdullah,A. (2014). Reflective Teaching and language Teacher Education Programs: A Milestone in Yemen and Saudia Arabia. Journal of Language Teaching and Research, Vol5., No.4, PP. 759-768 (July 2014)

Alsowat, H. (2016). An EFL Flipped Classroom Teaching Model: Effects on English Language Higher-order Thinking Skills, Student Engagement and Satisfaction. Journal of Education and Practice. ISSN 2222-1735(Paper) ISSN 2222 -288X (online) Vol.7, No.9. Pp108-121

Awad, R. (2009). The Effect of Using a Reflective Model of Teaching on Developing Second Year English Majors' SelfAssessment, Self-esteem and Teaching Skills. Unpublished Master Thesis. Faculty of Education- Minia University.

Barmhall,.et.al (2010). The Strategic Development of Learner Autonomy Through Enquiry Based Learning. Industry and Higher Education

Available at http://journals.sagepub.com/doi/abs/10.5367/00000001 0791191010?journalCode=ihea. Retrieved on 17-3-2018

Benson, P. (2001).Teaching and Researching autonomy in Language Learning. Harlow, Uk: Longman.

Bergmann, J. \&Sams ,A. (2014). Flipped Learning. Gateway to student engagement. International Society for Technology in Education. Eugene Oregon.

Borg,S.\&Al-Busaidi, S. (2012). Learner Autonomy : English Language Teachers Beliefs and Practices. ELT Research Paper 1207, British Council University of Leeds.

Brikena,X \& Gezim ,X (2011). Developing Learner Autonomy in Higher Education in Macedonia. Procedia Social and Behavioral Sciences. Available on line at www. Science direct.com. Retrieved on 21-3-2018

Cara, A. (2012). The Effect of the Flipped Classroom on students' Achievement and Stress. M.A Thesis. State University. Bozeman, Montana

Castle, K. (2004). The Meaning of Autonomy in Early Childhood Teacher Education. Journal of Early childhood Teacher Education, 25 (1), Pp3-10 
Chee\&San (2012). Reflective Thinking and Teaching Practices: A Precursor for Incorporating Critical Thinking Into the Classroom? International Journal of Instruction. Vol.5, No.1 p-ISSN: 1694-609X

Educause. (2012).7 Things you should know about Flipped Classrooms: Retrieved from

http://net.educause.edu/ir/liberary/pdf/EL7018/.pdf.

Retrieved on 14-1-2018

Emran, A. (2016). Investigating the Use of a Program Based on action Research Skills in Developing $3^{\text {rd }}$ Year Faculty of Education English Majors' Reflective Teaching Practice and Their performance. Unpublished M.A Thesis. Faculty of Education, Minia University.

Ellison, C.(2008). Reflective-make-and -take: a Talent quest reflective practice teacher model. Reflective Practice, 9(2), 185-195.

Fariba, M, Fatin, P \& Hamidreza, K. (2013). Measuring Teachers ' Reflective Thinking skills. Procedia-Social and Behavioral Sciences (640-647). Available online at www. Sciencedirect. Retrieved on 23-3-2018.

Fauzi, Sh.\&Huessein. R(2016). Designing Instruction for Active and Reflective learners in the Flipped Classroom. Malaysian Journal of Learning and Instruction. Vol.13, No.2 Pp147-173

Field, J. (2007). Looking outwards not inwards. ELT, vol .(6) Pp30-38

FLP(2014). The Four Pillars of FLIP learning. Available at www.Flipped learning .org/definition /Flipped learning. Retrieved on 23-12-2017

Graham, B. J. (2013). Student Perceptions of the Flipped Classroom. Master of Arts. The University of British Columbia

Halpern,D.F.(1996). " Thought and knowledge : an introduction to critical thinking" (3rd.ed.)Mahwah, NJ:L Erlbaum 
Associates.

Available

at:

http://www.higp.hawall.edu/kaams/resource/reflection

Han, L(2014). Teacher's Role in Developing Learner Autonomy : A Literature Review. International of English Language Teaching Vol.1,No2

Holec, H. (1980). Autonomy and Foreign Language Learning. Stasbourg: Council of Europe.

Honeycutt, B. \& Warren , S. (2014). Flipped classrooms : Tips for Integrating Moments of Reflection. Available at http://www.facultyfocus.com/articles/blended-flippedlearning/flipped-classroom-tips-integrating-momentsreflection. Retrieved on 13-1-2018

Ibrahim,I. (2006). The Effects of Using Portfolio-based Instruction on Developing Pre-service EFL Teachers' reflective thinking Skills and Teaching Skills. Unpublished M.A Thesis , Faculty of Education- Minia University.

James, A., Chin,C. \&Williams, B. (2014). Using the Flipped Classroom to Improve Student Engagement and to Prepare Graduates to Meet Maritime Industry Requirements: A Focus on Maritime Education. World Maritime University Marit Affairs 13:331-343 DOI 10.1007/s 13437-014-0070-0

Jarod, B. (2014). Affordances of Flipped Learning and Its Effects on Student Engagement and Achievement. M.A Thesis. University of Northern IOWA

Kettani, Y. (2014). The value of Learning Autonomy in Learning. Available at http://moroccoenglish.com/2014/03/30/thevalue-of-learner-autonomy-in-learning/ . Retrieved on 12 4-2018

Kiran, S (2014). Role of Flipped Classroom in Education. PARIPEX-Indian Journal of Research. Vol. 3, Issue 4.

Kizlik, B (2017): " Thinking Skills Vocabulary and Definitions", Online Education for Teachers, at the site: http:// www.adprima.comwho.htm. Retrieved on 25-12-2018 
Lai,G., and Calandra, B.(2010). Examining the Effects of Computer-Based Scaffolds on Novice Teachers' Reflective Journal Writing. Educational Technology Research and Development. Vol.58.PP421-437.

Lin, P \& Chen, H (2016). The Effects of Flipped classroom on learning effectiveness: using learning satisfaction as the mediator. World Transactions on Engineering and Technology Education (WIETE) Vol.14, No.2.

Lee, K. \& Lai, Y. (2017). Facilitating Higher -Order Thinking with the Flipped Classroom Model : a Student teacher's Experience in a Hong Kong Secondary School. Research and Practice in Technology Enhanced Learning.Vol.1,No.2

Little ,D. (2000). Learner autonomy and human interference: Some theoretical and practical consequences of a social interactive view of cognition, learning and language . In Sinclair et al.(eds)29-38

Matchett, M. (2005). The Reflective Teacher. Education and Training Inspectorate. Online: http://www.deni.gov.uk/. Retrieved on 12-2-2018

Matwiejczyk, L\& Alexander , M. (2016). Applying Flipped Learning to placement Preparation and Employability Skills Can It Be Done? Available at https://www.adelaide.edu.au/flippedclassroom/resources L12 Placement.pdf. Retrieved on 14-8-2018

Merc, A. (2015). The Effect of a Learning Autonomy Training on the Study habits of the First Year ELT Students. Educational Research and Reviews. Vol. 10 (4), pp 378-387.

Moeller,A. (2016). Autonomy and Self-Regulation in Language Learning. Available at www.wlnces.ncdpi.wikispaces.net/file/view/JigsawPieceSelfReg ulation.pdf. Retrieved on 23-4-2018

Moon, J. A. (1999). Reflection in learning and professional development: Theory and practice. London: Kogan Page. 
Morgan, J. (2015). The Difference Between Autonomy and SelfManagement. FORBES. Available at https://www.forbes.com/sites/jacobmorgan/2015/12/18 the-difference-between-autonomy-and-selfmanagement/\#1d9140b74545. Retrieved on 15-12-2017

Murray, G. L. (1999). Autonomy and Language Learning in a Simulated Environment. System, 27(3), 295-308.

Nassar, Y. (2006) (in Arabic). The Impact of the Effect Size on the Scientific Significance of the Results Gained from Quantitative Studies. Journal of Educational \& Psychological Sciences. Faculty of Education -Bahrain University. ISSN 3670-1726 Vol.7 No.2.

Orief, I. (2018). An Investigation into the Impact of the Flipped Classroom on Intrinsic Motivation (IM) and Learning Outcomes on an EFL Writing Course at a University in Saudi Arabia Based on Self-determination Theory (SDT). Ph.D Dissertation. University of Leicester

Ozturk, I.H. (2011). Curriculum Reform and Teacher Autonomy in Turky: The Case of the History Teaching. International Journal of Instruction, 4(2), 113-128

Reinders, H (2010). "Learner Autonomy FAQ".Available at www.innovationinteaching.org. Retrieved on 22-2-2018

Sinclair, B. (2002). Learner Autonomy: The next phase? In B, Sinclair. I. MCGrath \& T.Lamb (Eds), Learner autonomy, teacher autonomy: Future directions ( pp.4-14). Harlow: Longman

Roehl, A., Reddy, S. L., \& Shannon, G. J. (2013). The flipped classroom: An opportunity to engage millennial students through active learning strategies. Journal of Family \& Consumer Sciences, 105(2), 44-49

Sera, R. (2015). What is Reflective Teaching and Why is it important? Available at http:// www. Richmondshare.com .br/what-is-reflective-teaching-and-why-is-it-important/. Retrieved on 23-4-2018. 
Sonia, M (2010). Some Classroom Management Problems, their reasons and solutions. Teaching English, British Council. Available

https://www.teachingenglish.org.uk/blogs/soniam/someclassroom-management-problems-their-reasons-solutions. Retrieved on 21-12-2017

Stayer, J. (2012). How Learning in an inverted classroom influences classroom influences cooperation, innovation and Task orientation. Learning Environments Research, 15 (2), 171-193.

Stone, B. (2012). Flip your Classroom to Increase Active Learning and Student Engagement. 28th Annual Conference on Distance Teaching \& Learning, Madison, WI. Retrieved from http://www.uwex.edu/disted/conference/resource librar y/proceedings/56511 2012.pdf

Tetreault. P. (2006). The Flipped Classroom: Cultivating Student Engagement. Master of Education. Fraser University.

Tochon, F. (1999). Myths in Teacher Education: Towards Reflectively. Pedagogy Culture \& Society. Vol.7 No.2 Pp.345360

Vaughan, M. (2014). Flipping the learning: An investigation into the use of the flipped classroom model in an introductory teaching course. Education Research and Perspectives, 41, 25-41.

Wang, P. (2011). Constructivism and Learner autonomy in foreign language teaching and learning: To what extent does theory inform practice? Theory and Practice in Language Studies, 1 (3), 273-227

Woolfe, R. (1992). Experiential Learning in Workshops. In Hobbs, T.(ed.) 1992. Experiential Training : Practical Guidelines. London: Tavistock/ Roudledge, 1-13.

Yang, C (2017). An Investigation of the' Flipped Classroom' Pedagogy in Secondary English Language Classrooms. 
Journal of Information Technology Education: Innovation in Practices. Vol. 16, No.2 Pp: 1- 20

Yurdakul, C (2017). An Investigation of the Relationship between Autonomous Learning and Life Long Learning. International Journal of Educational Research Review.Vol.2 Issue 1, Pp-15-20. 